Journal of Clinical Investigation

Vol. 42, No. 11, 1963

\title{
AGGLUTINATION OF STORED ERYTHROCYTES BY A HUMAN SERUM. CHARACTERIZATION OF THE SERUM FACTOR AND ERYTHROCYTE CHANGES *
}

\author{
By F. L. OZER And H. CHAPLIN, JR. \\ (From the Departments of Medicine and Preventive Medicine, Washington University School \\ of Medicine, St. Louis, Mo.)
}

(Submitted for publication May 8, 1963 ; accepted July 22, 1963)

There have been four previous reports of human sera causing agglutination of stored but not of fresh red cells $(1-4)$. The sera are of special interest for two reasons. Since the agglutinins are active against the patients' own stored cells as well as against cells from other donors, one must consider whether such patients represent examples of autoimmune disease. Of more immediate practical importance, the sera provide a new means for studying the red-cell storage defect, since the agglutinins detect in the erythrocyte membrane a hitherto unrecognized alteration that progresses during in vitro storage concurrently with deterioration in cellular metabolism.

Characterization of the previously reported stored-cell agglutinins has been limited. The present communication describes detailed studies of a serum causing strong agglutination of stored human red cells. The serum factor responsible for the agglutination was shown to be a gamma macroglobulin. Studies of red cells during storage in vitro indicate that development of agglutinability is closely related to the alterations in erythrocyte glucose metabolism occurring during storage. Also included are the results of sixteen studies of erythrocyte survival in vivo that are designed to examine the relationship of agglutinability to nonviability of the stored cells.

\section{METHODS}

The patient was a 71-year-old woman whose chief complaints were abdominal swelling and progressive weakness. The principal positive physical findings were pallor and hepatosplenomegaly. Laboratory findings of special interest were: hemoglobin, $9.7 \mathrm{~g}$ per $100 \mathrm{ml}$; reticulocytes, $4.2 \%$; serum bilirubin concentration, nor-

* Work supported by U. S. Public Health Service research grant G-2918 (C5) from the National Cancer Institute, Bethesda, Md. mal; total serum protein concentration, $7 \mathrm{~g}$ per $100 \mathrm{ml}$ (albumin, $2.7 \mathrm{~g}$, globulin, $4.3 \mathrm{~g}$ ). Survival in vivo of $\mathrm{Cr}^{51}$-labeled, fresh, compatible, red cells of normal donors was moderately severely reduced, judged by redcell life-span $\left(\mathrm{Cr}^{51} \mathrm{t}_{\frac{1}{2}}\right.$, about 8 days) based on daily blood sampling for 1 week. Exploratory laparotomy revealed moderate hepatic enlargement, diffuse mesenteric and retroperitoneal lymph-node enlargement, and massive splenomegaly. Splenectomy was performed, and the patient's postoperative course was uneventful. Two units of blood were transfused before and two additional units during surgery. Although the patient was improved at the time of discharge and required no further transfusions, she died at home 7 months later of undetermined cause; necroscopy was not performed. The spleen removed at operation weighed $2,050 \mathrm{~g}$ and showed hyperplasia of the white pulp, with impaired follicle formation; each Malpighian corpuscle was surrounded by a margin of hyperplastic lymphoid cells. Lymph nodes revealed intact architecture, but were filled out with lymphoid elements without follicle formation. A liver sample from biopsy was not remarkable, and aspirated bone marrow revealed only generalized hyperplasia. A specific pathological diagnosis was not made.

\section{Studies of the serum factor}

The patient's serum was obtained from clotted or defibrinated blood; plasma was obtained in acid-citrate dextrose anticoagulant solution. ${ }^{1}$ Serum and plasma samples were stored frozen at $-20^{\circ} \mathrm{C}$ until used. Coldwater-precipitable protein was prepared by diluting the patient's serum with 10 vol of cold, demineralized water; after three washings, the precipitate was dissolved in isotonic phosphate buffered saline at $\mathrm{pH}$ 7.4. Additional pathologic sera were obtained from twelve patients with macroglobulinemia, two patients with $\beta_{2 \mathrm{~A}}$ myeloma, and one patient with nonspecific hyperglobulinemia. ${ }^{2}$ Normal human macroglobulin was prepared from pooled plasma as described by Franklin and Stanworth (5). Paper electrophoresis was performed in a Spinco model $\mathrm{R}$ cell, with barbital buffer at $\mathrm{pH} 8.6$, ionic strength 0.1 . Immunoelectrophoresis was by the

${ }^{1}$ ACD, formula A, National Institutes of Health, Bethesda, Md.

2 Several of these sera were made available through the courtesy of Dr. H. G. Kunkel, the Rockefeller Institute, New York, N. Y. 
method of Scheidegger as described by Wieme (6). Analytical ultracentrifugation was carried out at 59,000 $\mathrm{rpm}$ at $20^{\circ} \mathrm{C}$ in a Spinco model $\mathrm{E}$ ultracentrifuge. Sucrose gradient density ultracentrifugation was performed as described by Kunkel (7). Column chromatography was carried out with DEAE cellulose ${ }^{3}$ (1 $\mathrm{ml}$ serum to $6 \mathrm{~g}$ DEAE cellulose) by stepwise elution with phosphate buffers- $0.0175 \mathrm{M}$ at $\mathrm{pH} 6.3,0.1 \mathrm{M}$ at $\mathrm{pH} 5.9$, and $0.4 \mathrm{M}$ phosphate containing $0.2 \mathrm{M}$ sodium chloride at $\mathrm{pH}$ 5.2-and with Sephadex G-200 ${ }^{4}(1 \mathrm{ml}$ serum separated on a column $2.0 \times 40 \mathrm{~cm}$, with isotonic buffered saline at $\mathrm{pH} 7.4$ as the equilibrating and eluting solution). $p$-Hydroxymercuribenzoate ${ }^{5}$ (PMB), $N$-ethylmaleimide ${ }^{5}$ (NEM), $d l$-penicillamine, ${ }^{5}$ glutathione $^{5}(\mathrm{GSH})$, oxidized glutathione ${ }^{5}$ (GSSG) and mercaptopyridoxine ${ }^{6}$ were obtained from manufacturers. The compounds were added to serum (diluted 1/10 unless otherwise indicated) after being dissolved in isotonic buffered saline. Incubation was at $37^{\circ} \mathrm{C}$ or room temperature for 1 to 2 hours. Where indicated, after incubation, a sample of the treated serum was dialyzed for 16 to 24 hours at $4^{\circ} \mathrm{C}$ against 1,000 vol of isotonic buffered saline.

For agglutination tests, dilutions of serum were made in isotonic saline. The test cells were normal, group $O$ red cells that had been stored sterile at $4^{\circ} \mathrm{C}$ in the presence of trisodium citrate, balanced oxalate, or acidcitrate detrose anticoagulants until they exhibited $4+$ agglutination (i.e., $>90 \%$ of the cells agglutinated) when exposed to the patient's serum diluted $1 / 100$. One volume of $5 \%$ red-cell suspension was well mixed on an opaque glass plate with an equal volume of diluted serum. The plate was gently rocked for exactly 3 minutes, and the reactions were recorded by gross inspection; on occasion, microscopic examination was also performed.

\section{In vitro studies of erythrocyte changes}

Red cells. Blood from normal donors and from 30 patients with a variety of hematologic disorders was collected in sterile bottles containing ACD solution, balanced sodium and potassium oxalate, trisodium citrate, heparin, or disodium EDTA anticoagulants. In addition, red cells from 100 sterile clotted samples in bloodbank pilot tubing were examined, including one sample ${ }^{7}$ from an I-negative donor (8). Most of the metabolic studies were performed on red cells from a single healthy donor whose erythrocytes were known to exhibit normal glucose-6-phosphate dehydrogenase (G6PD) activity and normal proportions of $A_{1}$ and $A_{2}$ hemoglobin. Animal bloods were obtained aseptically from rats, rabbits, and dogs. Preparation of eluates from red cells and red-cell ghosts by heating at $56^{\circ} \mathrm{C}$ was performed as described by Chaplin and Cassell (9). De-

\footnotetext{
${ }^{3}$ Bio-Rad Laboratories, Richmond, Calif.

4 A. B. Pharmacia, Uppsala, Sweden.

"Sigma Chemical Co., St. Louis, Mo.

${ }^{B}$ Supplied by Merck \& Co., Darmstad, Germany.

i Provided through the courtesy of Dr. Richard Rosenfield.
}

pletion of erythrocyte membrane lipids by treatment with alumina was carried out as described by Lovelock (10). Sickling was induced in fresh homozygous (SS) sickle-cell blood by equilibration with a $95 \%$ nitrogen: $5 \%$ carbon dioxide gas mixture; reversal of sickling was accomplished by re-equilibration with a $97 \%$ oxygen : 3\% nitrogen mixture as described by Anderson and Chaplin (11). Fresh red cells were exposed to the enzymes trypsin, papain, ficin, and bromelin as described by Mollison (12). Crude neuraminidase was added in various concentrations to buffered saline suspensions of thrice-washed fresh red cells and incubated at $37^{\circ} \mathrm{C}$ for up to 2 hours.

In metabolic studies, red cells from fresh blood collected aseptically in ACD anticoagulant were washed three times in 10 vol of glucose-free phosphate-buffered

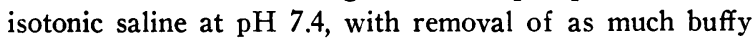
coat as possible after each centrifugation. 2-Desoxy-Dglucose, ${ }^{5} \mathrm{Na}$ arsenite ${ }^{5}$ (as $\mathrm{Na} m$-arsenite), $\mathrm{Na}$ arsenate ${ }^{5}$ (as dibasic salt), $\mathrm{Na}$ monoiodoacetate, $\mathrm{Na}$ fluoride, ${ }^{5}$ $\mathrm{PMB},{ }^{5}$ NEM, ${ }^{5}$ phlorizin, ${ }^{5}$ adenosine,${ }^{5}$ adenine, ${ }^{5}$ inosine, ${ }^{5}$ and methylene blue ${ }^{6}$ (MB) were obtained from manufacturers. Adenosine and NEM were dissolved in dilute $\mathrm{HCl}$ and neutralized to $\mathrm{pH} 7.4$ by $\mathrm{NaOH}$. The other reagents were dissolved directly in buffered isotonic saline. The thrice-washed red cells were made to a $50 \%$ suspension in buffered saline containing the reagents above, and the mixture was incubated in a Dubnoff metabolic shaker at 60 oscillations per minute and $37^{\circ} \mathrm{C}$ for 1 to 2 hours. After incubation, the red cells were washed once with $10 \mathrm{vol}$ of buffered saline, and a $5 \%$ suspension was immediately tested for agglutination as previously described.

\section{In vivo studies of erythrocyte changes}

Transfusion studies were performed in thirteen volunteers. Six were in normal health; four were hematologically normal hospital patients ; of the remaining three patients, one had acute myelomonocytic leukemia, one, sickle-cell trait, and one, chronic myelocytic leukemia. Altogether, $9 \mathrm{U}$ of outdated blood ${ }^{8}$ stored in ACD anticoagulant (mean length of storage, 30.5 days; range, 22 to 38 days) were employed in 16 transfusion studies to permit comparison of the survival in vivo of : a) untreated stored blood, $b$ ) unagglutinable cells recovered after removal of cells agglutinated by macroglobulinemic (MG) serum, and c) unagglutinable cells recovered from stored blood incubated with adenosine $(3 \mathrm{mmoles}$ per ml cells) for 1 hour either before or after the addition of MG serum. Four of the $9 \mathrm{U}$ were used for single studies of the survival of unagglutinable cells; the remaining $5 \mathrm{U}$ were used for multiple studies of untreated cells (controls) and unagglutinable cells recovered after exposure to MG serum.

Separation of unagglutinable cells before transfusion. A $5 \%$ suspension of stored cells in saline was incubated

8 Obtained from the Barnes Hospital Blood Bank or from the St. Louis Chapter of the American National Red Cross. 
for 10 minutes at room temperature with an appropriate amount of sterile MG serum previously heated at $60^{\circ} \mathrm{C}$ for 10 hours to eliminate the risk of transmission of serum hepatitis. Separation of the unagglutinated cells to be used for transfusion was accomplished either by aspirating the cells remaining in suspension after the agglutinates had been allowed to settle as sediment for 10 minutes, or by removing the agglutinates by passage through a Millipore filter (pore size, $10 \mu$ ). ${ }^{9}$ The percentage of the original cells remaining in the final suspension used for transfusion was estimated from duplicate measurements of oxyhemoglobin concentration and of turbidity of samples removed from the cell suspension before addition of the MG serum, and again after separation of the agglutinates, with suitable correction for dilution by the suspending medium. Comparable "recoveries" were obtained from both separation procedures, and averaged 50 to $60 \%$ of the original cells present. The "loss" (40 to $50 \%$ ) represents the combined losses from the agglutinates removed as well as residual unagglutinated cells remaining on the filters, glassware, etc. About $30 \%$ of the cells in the stored blood was estimated to be removed as agglutinates. Microscopic examination of the cell suspensions employed for transfusion revealed only occasional tiny agglutinates (never representing $>2 \%$ of the total cells present).

Red-cell survival in vivo was measured by the $\mathrm{Cr}^{51}$ method of Ebaugh, Emerson, and Ross (13). The labeled red cells were washed in at least $10 \mathrm{vol}$ of saline before injection, and measurement of radioactivity in the suspending medium confirmed that more than $99 \%$ of injected $\mathrm{Cr}^{51}$ was erythrocyte bound. The recipient's blood volume was measured by the simultaneous injection of Evans' blue dye. Blood samples were obtained 15,30 , and 45 minutes, and 1, 6, 24, and 48 hours after injection; additional samples were obtained at intervals of 3 to 5 days over the ensuing 2 to 4 weeks in most instances. An estimate of the expected immediate $100 \%$ survival was determined from the known volume of $\mathrm{Cr}^{51}$ labeled cells injected and the recipient's blood volume. Subsequent survival was determined from the radioactivity present per milliliter of whole blood and expressed as a percentage of the expected $100 \%$ survival. Radioactivity in plasma separate from all samples drawn within the first hour after transfusion never exceeded $1 \%$ of the activity present in the whole blood samples.

Relationship of agglutinability to chronological red-cell age. $\mathrm{Fe}^{50}, 19.5 \mu \mathrm{c}$, incubated for 45 minutes at $37^{\circ} \mathrm{C}$ in $25 \mathrm{ml}$ of autogenous plasma, was injected intravenously into a normal volunteer. Sterile blood samples were collected in ACD anticoagulant 19, 22, 42, 67, 78, and 110 days after injection and stored until about $30 \%$ of the cells became agglutinable by MG serum. A portion of the stored sample was treated with $M G$ serum, and the agglutinates were removed by filtration. Duplicate

9 Type OS solvent-resistant filters, Millipore Filter Corp., Bedford, Mass.
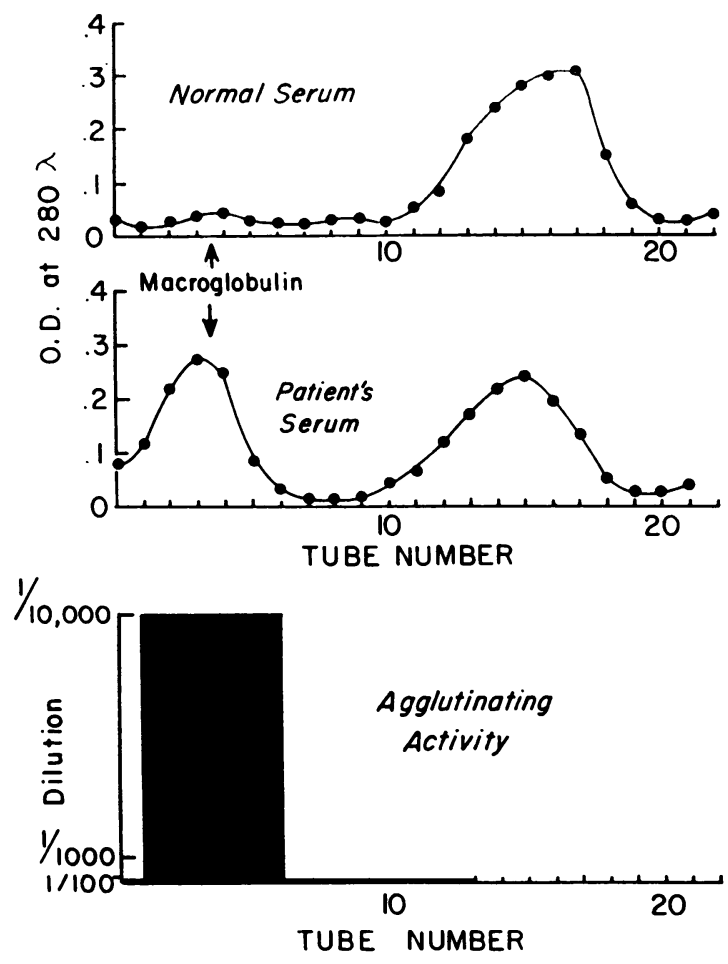

Fig. 1. Sucrose gradient density UltracentrifugaTION OF THE PATIENT'S SERUM COMPARED WITH A NORMAL SERUM. The stored-cell agglutinin activity was concentrated in the sedimented macroglobulin fraction.

hemoglobin determinations were made on the original blood sample and on the final suspension of unagglutinated cells. Radioactivity in the two samples was measured in a well-type scintillation counter and expressed as counts per minute per gram of hemoglobin.

\section{RESULTS}

\section{Characterization of the serum factor}

Fresh red cells from normal donors were unaffected by the patient's serum, but stored red cells from the same donors were agglutinated in increasing numbers with increasing time of storage. The agglutination reaction could be carried out equally well over a range of $\mathrm{pH}$ from 5.6 to 8.0 and of temperature from $4^{\circ}$ to $37^{\circ} \mathrm{C}$. Four plus agglutination was demonstrable with the serum diluted $1 / 10,000$, and positive agglutination was clearly definable up to dilutions of $1 / 100,000$ to $1 / 500,000$. The ability of the serum to agglutinate stored cells withstood heating at $60^{\circ} \mathrm{C}$ for 10 hours, but was destroyed after 10 minutes at $80^{\circ} \mathrm{C}$. 

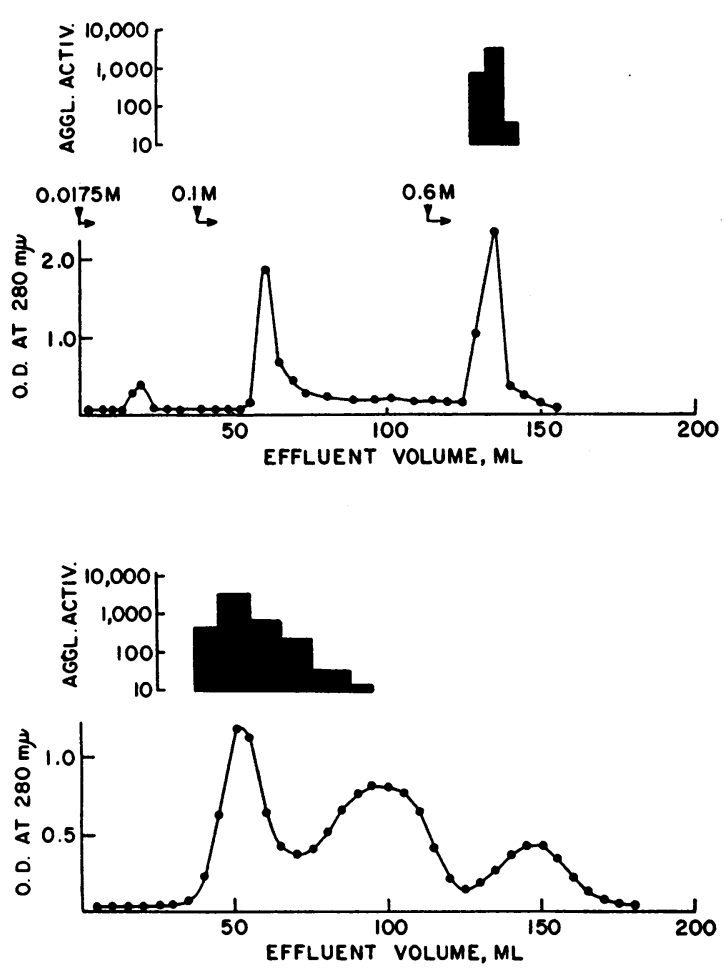

Fig. 2. DEAE-cellulose (top) and Sephadlx G-200 (BOTTOM) CHROMATOGRAPHY OF THE PATIENT'S SERUM. Stored-cell agglutinin activity appeared in the fractions in which high-molecular-weight globulins are concentrated.

Paper electrophoresis of the patient's serum showed a dense homogeneous band in the gamma globulin region. Immunoelectrophoresis demonstrated a heavy precipitin band in the gamma-1 position. Analytical ultracentrifugation revealed that $36.7 \%$ of the total serum protein was accounted for by two macroglobulins, $32.6 \%$ exhibiting an $\mathrm{S}_{20 \text {,w }}$ value of 18.8 , and $4.1 \%$, one of 28.8 .

Protein precipitated by $1 / 10$ dilution of serum with distilled water possessed strong agglutinating activity when redissolved. The results of sucrose gradient density ultracentrifugation (Figure 1) demonstrated that the agglutinating activity of whole serum was corcentrated in the macroglobulin fraction. Column chromatography on DEAE cellulose (14) and Sephadex G-200 (15) (Figure 2) revealed the agglutinating activity concentrated in the fractions richest in gamma macroglobulins. The $7 \mathrm{~S}_{\mathbf{2 0} \text {, w }}$ gamma globulin fraction eluted in the first DEAE-cellulose peak was incubated with stored cells in the presence and ab- sence of added complement; no agglutination was observed, and subsequent exposure to antihuman globulin serum revealed no evidence of "incomplete" stored-cell agglutinating activity.

Treatment of a $1 / 10$ dilution of serum with disulfide-splitting agents- $d, l$-penicillamine (16) (10 $\mathrm{mg}$ per $\mathrm{ml})$, mercaptopyridoxine (16) (10 $\mathrm{mg}$ per $\mathrm{ml})$, or GSH $(17-21)\left(4 \times 10^{-2} \mathrm{M}\right)-$ resulted in complete loss of agglutinating activity and disappearance of the macroglobulin peaks previously seen on ultracentrifugation. Reaggregation of the protein subunits did not occur after dialysis of the treated serum, nor was the agglutinating activity restored. Furthermore, stored red cells incubated with the treated serum either before or after dialysis failed to agglutinate upon the addition of rabbit antihuman globulin serum, nor did they appear "blocked" when exposed to the patient's untreated serum.

Sulfhydryl ( $\mathrm{SH})$-binding agents such as $\mathrm{PMB}$ $(22,23)$, GSSG $(20,21)$, and $\mathrm{Na}$ arsenite (23-26) at concentrations of 2 to $5 \times 10^{-2} \mathrm{M}$ abolished agglutinating activity. Ultracentrifugation patterns of the serum remained unchanged (Figure 3) except for loss of the $28.8 \mathrm{~S}_{\mathbf{2 0 , w}}$ peak from the $\mathrm{Na}$ arsenite-treated sample. After dialysis, strong agglutinating activity was restored in all samples. NEM (27) inhibited the agglutinating activity only at high concentrations $\left(2 \times 10^{-1} \mathrm{M}\right)$; the inhibition was not reversible after dialysis.

TABLE I

Effect of anticoagulant solutions on agglutinability of red blood cells stored at $4^{\circ} \mathrm{C}$

\begin{tabular}{|c|c|c|c|c|c|}
\hline \multirow[b]{2}{*}{ Anticoagulant } & \multicolumn{5}{|c|}{ Agglutination after days of storage } \\
\hline & $\mathbf{0}$ & 2 & 6 & 12 & 21 \\
\hline Oxalate & - & $1+$ & $3+$ & $4+$ & $4+$ \\
\hline Citrate & - & - & $1+$ & $3+$ & $4+$ \\
\hline Heparin & - & - & $1+$ & $3+$ & $4+$ \\
\hline EDTA & - & - & $1+$ & $1-2+$ & $4+$ \\
\hline Acid-citrate dextrose & - & \pm & $1+$ & $1+$ & $2+$ \\
\hline
\end{tabular}

Ten of twelve MG sera, one of two $\beta_{2 \mathrm{~A}}$ myeloma sera, and a macroglobulin fraction prepared from pooled normal sera showed no agglutination of stored cells. Weak agglutination of stored cells at serum dilutions of $1 / 10$ or less was observed with samples from two patients with primary macroglobulinemia and one patient with $\beta_{2 \mathrm{~A}}$ myeloma. 


\section{In vitro studies of erythrocyte changes}

Agglutination. The presence of the stored-cell agglutinin in MG serum was first revealed when marked agglutination was observed during routine cross-matching procedures employing the patient's serum and group-compatible red cells from clotted pilot tube samples that had been stored for 5 to 21 days in the hospital blood bank. No agglutination was observed when freshly drawn donor blood was employed. Factors in the donor's serum were not necessary to effect the agglutinability of stored cells; in fact, agglutinability always developed faster if the freshly drawn cells were washed free of serum before storage. Identical results were obtained with 100 consecutive, sterile, group-compatible, normal-donor pilot samples, including one sample of $\mathrm{I}(-)$ cells. Similar findings were obtained with samples of Vel (-), Dc-/Dc-, Lu(a-b-) cells, and with $\mathrm{P}_{1}$ - and $\mathrm{P}$-negative (but $\mathrm{P}^{\mathrm{k}}$-positive) cells. ${ }^{10}$ Specificity of the agglutinin for human cells was suggested by failure of MG serum to cause agglutination of rat, rabbit, or dog red cells, either freshly obtained or after prolonged storage.

Effects of various anticoagulants during storage at $4^{\circ} \mathrm{C}$. Blood samples obtained from five normal donors were tested, with essentially similar results in all. Results for a single donor are illustrated in Table I. Red cells in oxalated blood became positive on day 2 ; by day 12 , almost all

TABLE II

Effect of anticoagulant solutions on agglutinability of red blood cells stored at $37^{\circ} \mathrm{C}$

\begin{tabular}{lccc}
\hline & \multicolumn{3}{c}{ Agglutination after hours of storage } \\
\cline { 2 - 4 } \multicolumn{1}{c}{ Anticoagulant } & 5 & 10 & 24 \\
\hline Oxalate & $1+$ & $3+$ & $4+$ \\
Defibrination & - & $1+$ & $4+$ \\
Heparin & - & $1+$ & $4+$ \\
Acid-citrate dextrose & - & $1+$ & $2+$ \\
\hline
\end{tabular}

the cells were agglutinable. When citrate, heparin, or EDTA were employed, positive reactions first appeared on day 3 or 4 , becoming $4+$ by the third week. In the presence of $\mathrm{ACD}$, a weakly positive reaction appeared on day 2 ; it remained $1+$ for 2 weeks and was only $2+$ af-

\footnotetext{
${ }^{10}$ Kindly tested by Dr. Ruth Sanger, Blood Group Research Laboratory, Lister Institute, London, England.
}

REVERSIBLE INHIBITION OF AGGLUTINATING ACTIVITY (Mocroglobulin not broken down)

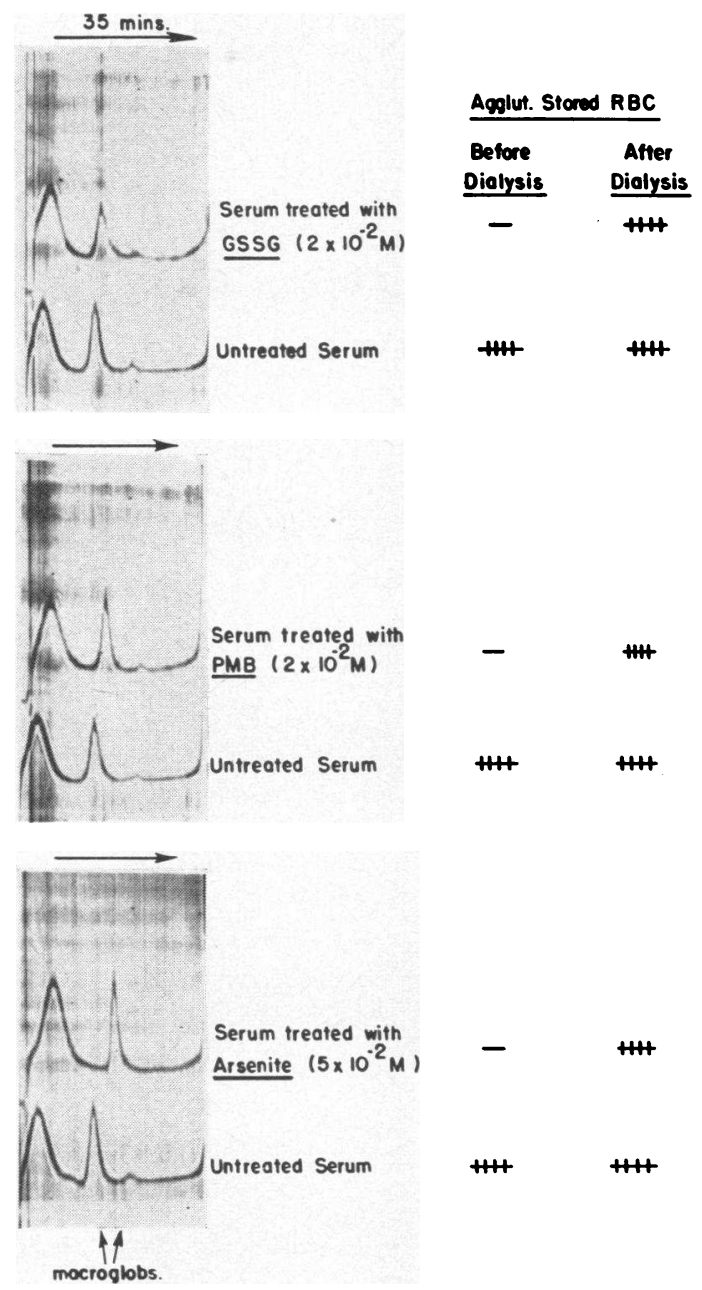

Fig. 3. Ultracentriflgation patterns of the PaTIENT'S SERUM AFTER TREATMENT WITH SULFHYDRYL-BINDING AGENTS. Although the major macroglobulin peak was not altered, stored-cell agglutinin activity was abolished. Inhibition of agglutinin activity was reversible in each instance after dialysis against $0.145 \mathrm{M}$ buffered saline, pH 7.4.

ter 21 days of storage; a $4+$ reaction was not observed in ACD blood until after about 6 weeks of storage.

Effects of various anticoagulants during storage at $37^{\circ} \mathrm{C}$. Samples from two normal donors gave similar results, summarized in Table II. Oxalated blood again was the first to become positive, showing a $1+$ reaction after 5 hours of storage. By 10 hours, it exhibited a $3+$ reaction, while defibrinated, heparinized, and ACD bloods were $1+$. After 24 hours at $37^{\circ} \mathrm{C}$. all 




Fig. 4. LOW-POWER PHOTOMICROGRAPHS OF AGgLUTINATION OBSERVED WITH INCREASING DURATION OF STORAGE. Whatever the strength of the reaction, the picture is always one of discrete agglutinates against a smooth background of unagglutinated cells.

the cells were agglutinable except those stored in ACD solution, which showed only a $2+$ reaction.

Quantitation of agglutination. Figure 4 shows low-power photomicrographs of agglutination reactions, graded as 1 to $4+$, observed with normal human red cells after progressively longer periods of storage. A striking feature of the reactions is the presence of discrete masses of strongly agglutinated cells in the midst of other cells that are completely unaffected and form a smooth homogeneous background. It was therefore possible to quantitate the agglutination by counting the number of cells that remained unagglutinable after exposure to MG serum. Good reproducibility of the inagglutinable counts could be achieved for $3+$ and $4+$ reactions; results were less satisfactory for $1+$ and $2+$ reactions.

Effects of purine nucleosides. We have already shown (Tables I and II) that the development of agglutinability during storage is delayed in ACD solution, which is known to prolong the viability of red cells during storage by providing glucose as substrate and slowing glycolysis at acid $\mathrm{pH}$ (28). Since improved preservation of stored red cells has been reported after addition of certain purine nucleosides (29-31), the effects of adenosine and inosine ( 0.03 to $10 \mathrm{mM}$ ) were studied in relation to the development of agglutinability. The nucleosides were added to either thrice-washed red cells or whole blood and incubated for 1 hour at $37^{\circ} \mathrm{C}$. An increased effect of inhibition or reversal of agglutinability was observed as the concentration of nucleoside was raised from 0.03 to $3 \mathrm{mM}$; further enhancement was not observed at $10 \mathrm{mM}$ concentration. Results of an experiment using 33-day-old ACD blood are shown in Table III. The ameliorating effect of adenosine is clearly evident. In this particular experiment, inosine showed no beneficial effect; in other experiments, moderate reduction in agglutinability was observed after incubation with inosine, although never so much as with adenosine. The combination of inosine with adenosine was not better than adenosine alone. 
TABLE III

Effect of nucleosides on red blood cells stored 33 days in ACD

\begin{tabular}{|c|c|c|c|c|}
\hline \multirow[b]{2}{*}{ Additive } & \multicolumn{4}{|c|}{ Agglutination by dilutions of patient's serum } \\
\hline & $1 / 10$ & $1 / 50$ & $1 / 100$ & $1 / 1,000$ \\
\hline $\begin{array}{l}\text { None (control) } \\
\text { Adenosine, } 3 \text { mmoles per } \mathrm{ml} \text { of cells } \\
\text { Adenosine }+ \text { inosine } \\
\text { Inosine, } 3 \text { mmoles per } \mathrm{ml} \text { of cells }\end{array}$ & $\begin{array}{l}2-3+ \\
1+ \\
1+ \\
2-3+\end{array}$ & $\begin{array}{l}2-3+ \\
1+ \\
1+ \\
2-3+\end{array}$ & $\begin{array}{l}2-3+ \\
1+ \\
1+ \\
2-3+\end{array}$ & $\begin{array}{l}2-3+ \\
\quad \pm \\
\quad \pm \\
2-3+\end{array}$ \\
\hline
\end{tabular}

When oxalated blood had become agglutinable after incubation at $37^{\circ} \mathrm{C}$ for 5 to 8 hours, agglutinability could be completely reversed by addition of adenosine. Oxalated blood incubated at $37^{\circ} \mathrm{C}$ for longer than 8 hours showed only partial improvement after addition of adenosine, with the number of irreversibly agglutinable cells increasing with increasing length of storage.

Adenosine was capable of exerting its effect on agglutinability even when added to cells already agglutinated by MG serum. For example, a suspension of long-stored cells developed $4+$ agglutination after addition of $\mathrm{MG}$ serum. If adenosine was then added to the suspension of agglutinates and incubation carried out at $37^{\circ} \mathrm{C}$ for 30 to 45 minutes, the size of the agglutinates decreased, numerous unagglutinated cells appeared free in the suspending medium, and the $4+$ reaction was thereby converted to a 2 to $3+$ reaction. A control suspension of agglutinates, without addition of adenosine, continued to show a $4+$ reaction after the incubation at $37^{\circ} \mathrm{C}$.

Beneficial effects on red-cell preservation have recently been reported when small amounts of adenine ( 0.75 to $1.0 \mu$ moles per $\mathrm{ml}$ cells) are added to the blood before storage (32). In this study, agglutinability of stored cells was not reduced after incubation with adenine $(0.75 \mu$ mole to 3 mmoles per $\mathrm{ml}$ cells) for up to 2 hours at $37^{\circ} \mathrm{C}$ and up to 48 hours at $4^{\circ} \mathrm{C}$. No studies were carried out on adenine in combination with inosine.

Effects of agents deleterious to maintenance of erythrocyte glucose metabolism. In each of ten experiments, the addition of methylene blue (MB) to fresh red cells hastened agglutination during incubation at $37^{\circ} \mathrm{C}$. The effect of $\mathrm{MB}$ varied directly with the concentration employed, as Table IV shows. If glucose $(0.2 \mathrm{M})$ or adenosine (3 mmoles per $\mathrm{ml}$ cells) were added at the same time as $\mathrm{MB}$, the appearance of agglutinable cells could be prevented. If glucose or adenosine were added after the appearance of agglutinable cells, agglutinability could be completely reversed, even with high concentrations of $\mathrm{MB}$ ( 3 mmoles per $\mathrm{ml}$ cells). G6PD-deficient cells exhibited an approximately doubled susceptibility to the effect of $\mathrm{MB}$ compared to normal cells. Moreover, the enhanced agglutinability of G6PD-deficient cells exposed to MB was not prevented or abolished by addition of glucose or adenosine.

Incubation with 2-desoxy-D-glucose (1.6 mmoles per $\mathrm{ml}$ cells) rendered a small proportion of fresh cells agglutinable, and more of them with increasing concentrations of 2-desoxy-D-glucose (ten experiments). At a concentration of 9 mmoles

TABLE IV

Effect of incubation with methylene blue $(M B)$ for 1 hour at $37^{\circ} \mathrm{C}$ on the agglutinability of fresh red blood cells

\begin{tabular}{|c|c|c|c|c|c|c|}
\hline \multirow[b]{2}{*}{ Concentration of $\mathrm{MB}$} & \multicolumn{6}{|c|}{ Agglutination by dilutions of patient's serum } \\
\hline & $1 / 1$ & $1 / 10$ & $1 / 50$ & $1 / 100$ & $1 / 1,000$ & $1 / 10,000$ \\
\hline \multicolumn{7}{|l|}{ moles $/ m l R B C$} \\
\hline $5.10^{-6}$ & \pm & \pm & - & - & - & - \\
\hline $5.10^{-5}$ & $1+$ & $1+$ & $1+$ & \pm & - & - \\
\hline $.10^{-4}$ & $1+$ & $1+$ & $1+$ & \pm & - & - \\
\hline $1.0 \times 10^{-3}$ & $1-2+$ & $1-2+$ & $1+$ & $1+$ & $1+$ & $1+$ \\
\hline $1.6 \times 10^{-3}$ & $3+$ & $3+$ & $2+$ & $2+$ & $1-2+$ & $1+$ \\
\hline $3.3 \times 10^{-3}$ & $3-4+$ & $3-4+$ & $3-4+$ & $3+$ & $3+$ & $2+$ \\
\hline Control (fresh RBC) & - & - & - & - & - & - \\
\hline
\end{tabular}


TABLE V

Agglutinating activity of eluates prepared from stored $R B C$, fresh $R B C$, and ghosts prepared from stored $R B C$

\begin{tabular}{|c|c|c|c|c|c|c|c|c|c|c|}
\hline \multirow[b]{2}{*}{ Source of eluates } & \multicolumn{10}{|c|}{ Agglutination by dilutions of eluates } \\
\hline & $1 / 1$ & $1 / 2$ & $1 / 4$ & $1 / 8$ & $1 / 16$ & $1 / 32$ & $1 / 64$ & $1 / 128$ & $1 / 256$ & $1 / 512$ \\
\hline $\begin{array}{l}\text { Stored RBC } \\
\text { Fresh RBC } \\
\text { Ghosts from stored RBC } \\
\text { Patient's serum (control) }\end{array}$ & $\begin{array}{l}4+ \\
1-2+ \\
1+ \\
4+\end{array}$ & $\begin{array}{c}4+ \\
1-2+ \\
\pm \\
4+\end{array}$ & $\begin{array}{c}4+ \\
1-2+ \\
- \\
4+\end{array}$ & $\begin{array}{c}3-4+ \\
1+ \\
4+\end{array}$ & $\begin{array}{c}3-4+ \\
1+ \\
- \\
4+\end{array}$ & $\begin{array}{c}3+ \\
1+ \\
- \\
3-4+\end{array}$ & $\begin{array}{l}3+ \\
1+ \\
- \\
3+\end{array}$ & $\begin{array}{l}2+ \\
1+ \\
3+\end{array}$ & $\begin{array}{l}2+ \\
1+ \\
3+\end{array}$ & $\begin{array}{l}2+ \\
1+ \\
\overline{3+}\end{array}$ \\
\hline
\end{tabular}

per $\mathrm{ml}$ cells, 2-desoxy-D-glucose caused hemolysis of red cells suspended in saline; when a nonpenetrating, osmotically active substance was present in the suspending medium (e.g., $0.31 \mathrm{M}$ sucrose in water, or $25 \%$ albumin in saline), hemolysis did not occur, and the red cells continued to show enhanced agglutinability. Equimolar glucose or 3 mmoles of adenosine per $\mathrm{ml}$ cells prevented or reversed the effect of 2-desoxy-D-glucose when the latter was present at concentrations of 6.4 mmoles per $\mathrm{ml}$ cells, or less. At higher concentrations of 2-desoxy-D-glucose, glucose and adenosine were only partially effective in diminishing the number of agglutinable cells.

When fresh red cells were incubated in the presence of phlorizin ( 2 mmoles per $\mathrm{ml}$ cells $)$, a small proportion was rendered agglutinable; more cells became agglutinable when increasing concentrations of phlorizin were employed (six experiments). Similarly, a small proportion of red cells became agglutinable when incubated in the presence of 3 mmoles per $\mathrm{ml}$ cells of $\mathrm{Na}$ arsenite, arsenate, monoiodacetate, or fluoride, with increasing numbers of cells affected at increasing concentra'ions of the reagents (six experiments).
Agglutinability provoked by these reagents was not prevented or reversed by adenosine.

Effects of $P M B$ and NEM. When fresh red cells were incubated with $\mathrm{PMB}$ and with NEM (six experiments), the minimal concentrations required to provoke agglutinability were 0.4 and 2 mmoles per $\mathrm{ml}$ cells, respectively. Both $\mathrm{PMB}$ and NEM caused hemolysis of red cells suspended in saline; hemolysis could be prevented without lessened agglutinability if $0.31 \mathrm{M}$ sucrose, or $25 \%$ albumin in saline were employed as the suspending medium. Again, no preventive or restorative effects of adenosine could be demonstrated.

Effects of direct alteration of the red-cell membrane. Depletion of cell membrane lipids by treatment with alumina sufficient to render the cells susceptible to hemolysis by thermal shock (33) failed to render any of the cells agglutinable by MG serum. Furthermore, agglutinability was not exhibited by the small proportion of red cells recoverable after brief periods of freezing and thawing. The presence of free hemoglobin in the suspending medium could not be held responsible for the lack of agglutination, since hemoglobin exerted no inhibitory effect on the agglutination

TABLE VI

Absorption of stored-cell agglutinin by ghosts prepared from stored red blood cells

\begin{tabular}{|c|c|c|c|c|c|c|c|c|c|c|}
\hline \multirow[b]{2}{*}{ Diluent of patient's serum } & \multicolumn{10}{|c|}{ Agglutination by dilutions of patient's serum } \\
\hline & $1 / 200$ & $1 / 400$ & $1 / 800$ & $1 / 1,600$ & $1 / 3,200$ & $1 / 6,400$ & $1 / 12,800$ & $1 / 25,600$ & $1 / 51,200$ & $1 / 102,400$ \\
\hline $\begin{array}{l}\text { Saline } \\
\text { Suspension of stored- } \\
\text { cell ghosts* }\end{array}$ & $\begin{array}{l}2-3+ \\
2-3+\end{array}$ & $\begin{array}{c}2-3+ \\
2+\end{array}$ & $\begin{array}{c}2-3+ \\
1+\end{array}$ & $\begin{array}{c}2-3+ \\
\pm\end{array}$ & $\stackrel{2+}{-}$ & $2+$ & $\stackrel{1+}{-}$ & $1+$ & $1+$ & \pm \\
\hline $\begin{array}{l}\text { Suspension of PMB- } \\
\text { treated ghosts } \dagger\end{array}$ & $2-3+$ & $2-3+$ & $2-3+$ & $2-3+$ & $2+$ & $2+$ & $1+$ & $1+$ & \pm & - \\
\hline
\end{tabular}

* Ghosts were prepared from long-stored cells by hypotonic lysis in weakly acidified distilled water. After repeated washing, the ghosts were made to a $25 \%$ suspension in saline and employed as the diluent for the titration. After 15 minutes of incubation at room temperature, the tubes were centrifuged and the clear supernatant fluids tested for agglutinating activity.

+ Ghosts were prepared as above, incubated at room temperature for 1 hour with $p$-hydroxymercuribenzoate $(4$ mmoles per $\mathrm{ml}$ of cells), washed, resuspended in saline, and employed as the diluent for titration. 
reaction when it was added to long-stored cells exposed to MG serum.

That the agglutination phenomenon involved actual binding of the agglutinin to the cell membrane was demonstrated in each of three studies of elution of the agglutinin by heating for $10 \mathrm{~min}-$ utes at $56^{\circ} \mathrm{C}$. Table $\mathrm{V}$ illustrates the agglutinating activity demonstrable in eluates prepared from intact fresh and long-stored cells, and from ghosts prepared from long-stored cells previously exposed to MG serum. Striking agglutinating activity was present in the stored-cell eluate, and weak but undoubted activity in the eluate from fresh cells, despite the complete absence of agglutinates in the fresh-cell preparation. It is not possible to say whether the weakly positive eluate from fresh cells implies the presence of reactive sites on the "fresh" red cell in vivo, since the time for the in vitro sensitization and eluation procedures could be sufficient to permit a minimal "storage" effect to become manifest. The very low activity demonstrable in the eluate from the stored-cell ghosts suggests that preparation of the ghosts (by hypotonic lysis in weakly acidified water) either liberated or inactivated the agglutinin. That ghosts retain their ability to react with the agglutinin was shown by four absorption studies; a typical result is illustrated in Table VI. The serum serially diluted in ghost suspension demonstrated diminished agglutinating activity compared to serum diluted in saline alone. Pretreatment of the ghosts with PMB inhibited their capacity to absorb the agglutinin.

Effects of proteolytic enzymes. Fresh red cells could be rendered agglutinable by treatment with trypsin, papain, ficin, bromelin, and neuraminidase (Table VII). Freshly prepared bromelin was the most effective; a $1+$ reaction was demonstrable after only 1 minute of exposure to the enzyme, and all the cells were agglutinable after exposure for 15 minutes. Red cells treated for 4 hours with bromelin showed no decline in their agglutinability, indicating that the reactive sites were not decomposed by the enzyme.

Agglutinability of abnormal cells. Table VIII summarizes the results of tests on fresh cells from thirty patients with hematologic abnormalities. All were negative except for the five patients with sickle-cell anemia (homozygous SS disease); in them, a weakly positive reaction

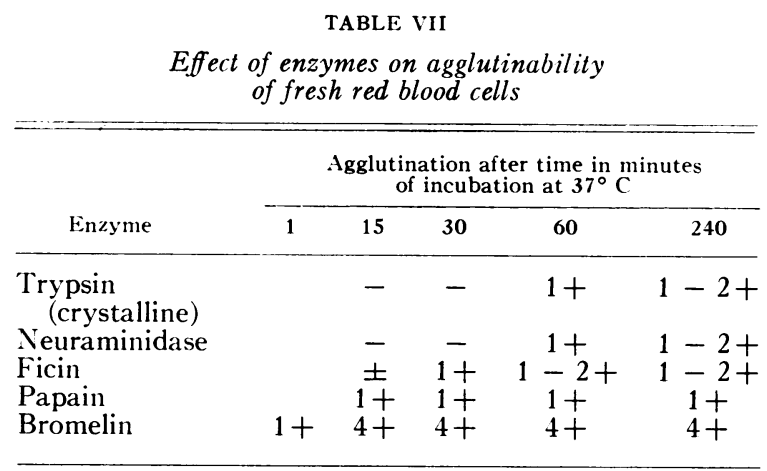

was uniformly observed, even with cells tested within 1 minute of obtaining the blood sample. Fresh cells from patients heterozygous for $\mathrm{S}$ hemoglobin were not agglutinable. Since 1 to $2 \%$ of sickled cells are invariably present in freshly drawn blood from patients with sickle-cell anemia, the effect of in vitro sickling was investigated. The weakly positive reactions were neither enhanced nor diminished when tested after complete deoxygenation ( $>90 \%$ cells sickled) and

TABLE VIII

Agglutinability of fresh erythrocytes from patients with hematologic disorders

\begin{tabular}{|c|c|c|}
\hline Hematologic disorder & $\begin{array}{l}\text { No. of } \\
\text { patients }\end{array}$ & $\begin{array}{l}\text { Agglutination by } \\
\text { macroglobulinemic } \\
\text { serum }\end{array}$ \\
\hline $\begin{array}{l}\text { Paroxysmal nocturnal hemo- } \\
\text { globinuria }\end{array}$ & 1 & - \\
\hline $\begin{array}{l}\text { Pernicious anemia (treated for } 1 \\
\text { week) }\end{array}$ & 1 & - \\
\hline Congenital spherocytosis & 2 & - \\
\hline $\begin{array}{l}\text { Acquired hemolytic anemia } \\
(\text { Coombs }+)\end{array}$ & 5 & - \\
\hline $\begin{array}{l}\text { Acquired hemolytic anemia } \\
\quad(\text { Coombs - })\end{array}$ & 2 & - \\
\hline Umbilical cord blood & 2 & - \\
\hline $\begin{array}{l}\text { Glucose-6-phosphate dehydro- } \\
\text { genase deficiency (hemizygous) }\end{array}$ & 2 & - \\
\hline Galactosemia & 1 & - \\
\hline Sickle-cell trait (SA Hgb) & 2 & - \\
\hline Sickle-cell thalassemia (SAF Hgb) & 1 & - \\
\hline Sickle-cell disease (SS Hgb) & 5 & + \\
\hline Thalassemia minor & 1 & - \\
\hline Iron-deficiency anemia & 2 & - \\
\hline Agnogenic myeloid metaplasia & 1 & - \\
\hline Elliptocytosis trait & 1 & - \\
\hline $\begin{array}{l}\text { Elliptocytosis with hemolytic } \\
\text { anemia (GSH deficiency) }\end{array}$ & 1 & - \\
\hline
\end{tabular}


TABLE IX

Agglutinability of abnormal red blood cells after incubation for 24 hours at $37^{\circ} \mathrm{C}$ (whole blood stored in acid-citrate dextrose)

\begin{tabular}{|c|c|c|c|c|}
\hline \multirow[b]{2}{*}{ Source of $\mathbf{R B C}$} & \multicolumn{4}{|c|}{ Agglutination by dilutions of patient's serum } \\
\hline & $1 / 10$ & $1 / 50$ & $1 / 100$ & $1 / 1,000$ \\
\hline Thalassemia minor (1 patient) & $2+$ & $4+$ & $4+$ & $3+$ \\
\hline Iron-deficiency anemia (1 patient) & $2+$ & $3+$ & $4+$ & $3+$ \\
\hline Coombs-positive acquired hemolytic anemia ( 3 patients) & $\begin{array}{l}4+ \\
3+ \\
3+\end{array}$ & $\begin{array}{l}3+ \\
3+ \\
3+\end{array}$ & $\begin{array}{l}2-3+ \\
2-3+ \\
2-3+\end{array}$ & $\begin{array}{l}2+ \\
2+ \\
2+\end{array}$ \\
\hline Elliptocytosis trait & $1-2+$ & $1+$ & $1+$ & $1+$ \\
\hline Elliptocytosis with GSH deficiency & $1-2+$ & $1+$ & $1+$ & $1+$ \\
\hline Normal donor (control) & $1-2+$ & $1+$ & $1+$ & $1+$ \\
\hline
\end{tabular}

after subsequent reoxygenation ( 1 to $2 \%$ cells sickled).

Although fresh samples of hematologically abnormal blood failed to exhibit agglutinability, clearly discernible differences from normal blood could be demonstrated after incubation of sterile ACD samples at $37^{\circ} \mathrm{C}$. Results of the seven ab-

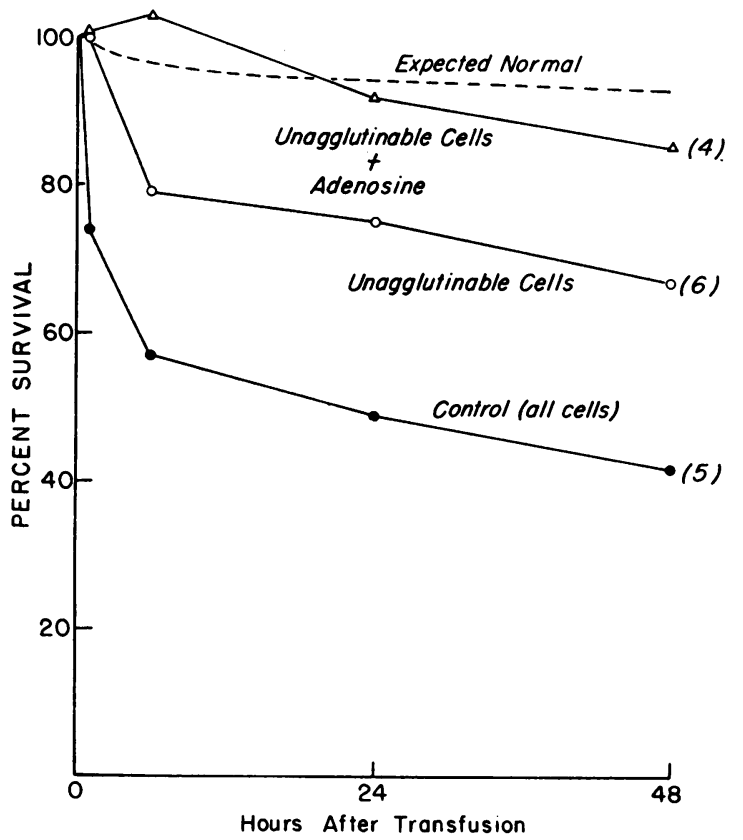

Fig. 5. Relationship of agglutinability to NONVIABILITY STUDIED BY TRANSFUSION OF $\mathrm{C}^{31}$-LABELED STORED BLOOD BEFORE AND AFTER SEPARATION OF CELLS AGglutinable BY MG SERUM. Mean length of storage was 30.5 days at $4^{\circ} \mathrm{C}$ in acid-citrate dextrose (ACD) anticoagulant. The effect of incubation with adenosine $(3$ mmoles per $\mathrm{ml}$ of cells) for 1 hour before transfusion is also shown. Numbers in parentheses indicate the numbers of separate studies performed. normal bloods tested are shown in Table IX. Five exhibited $3+$ or $4+$ agglutination after 24 hours of incubation, compared with $1+$ and $2+$ reactions for normal cells. Two examples of elliptocytotic blood gave normal results; these samples also failed to exhibit abnormal autohemolysis after sterile incubation $(34,35)$.

\section{In vivo studies of erythrocyte changes}

Survival of stored cells after transfusion. Fresh red cells labeled with chromium, incubated with MG serum, and passed through Millipore filters showed an entirely normal initial survival and a normal disappearance rate over the succeeding month $\left(\mathrm{Cr}^{51} \mathrm{t}_{\frac{1}{2}}, 27.5\right.$ days). Figure 5 summarizes the results of the 15 survival studies carried out on $9 \mathrm{U}$ stored blood (mean length of storage, 30.5 days). When whole blood (control) was administered, $71 \%$ of the cells were surviving at 1 hour after transfusion, $53 \%$ at 6 hours, $48 \%$ at 24 hours, and $39 \%$ at 48 hours. If the agglutinable cells were first removed and only the unagglutinable cells were transfused, survival was much improved, to $98 \%$ at 1 hour, $79 \%$ at 6 hours, $77 \%$ at 24 hours, and $69 \%$ at 48 hours. Survival of inagglutinable cells recovered after treatment of the whole blood with adenosine showed further improvement, with survival of $100 \%$ at 1 and 6 hours, $93 \%$ at 24 hours, and $88 \%$ at 48 hours. Whenever survival was observed for 2 to 4 weeks after transfusion, a normal rate of destruction was demonstrated for cells surviving beyond 48 hours.

Bromelin-treated blood after transfusion. Fresh $\mathrm{Cr}^{51}$-labeled red cells were exposed to bromelin 
for 15 minutes, then washed four times in $100 \mathrm{vol}$ saline. A sample tested with a $1 / 100$ dilution of MG serum revealed $4+$ agglutination. The remaining cells (not exposed to MG serum) were infused to the original donor. Eighty-nine per cent were present in the circulation at 1 hour after infusion, $71 \%$ at 3 hours, and $22 \%$ at 20.5 hours.

Relationship of agglutinability to chronological $r c d$-cell age. $\mathrm{Fe}^{59}$ was administered to a normal volunteer, and samples were obtained for storage studies at intervals over the succeeding 110 days. In vitro storage was continued long enough to render 30 to $40 \%$ of the cells agglutinable by MG serum. Radioactivity per gram of hemoglobin in the whole samples was then compared with that in suspensions from which the agglutinable cells had been removed. We reasoned that if the development of agglutinability was directly related to chronological cell age, then the ratios of radioactivity in suspensions of unagglutinable cells to radioactivity in the whole sample would be $>1.0$ (maximum, approximately 1.4) during the early phases of the study, and would fall to $<1.0$ (minimum, approximately 0.2 ) near the end of the life-span of the labeled cells. If, on the other hand, development of agglutinability was unrelated to chronological cell age, the ratios would approximate 1.0 throughout the study. The results are illustrated in Figure 6; five of the six samples revealed ratios between 0.92 and 1.02, indicating that the development of agglutinability during in vitro storage was unrelated to chronological red-cell age.

\section{DISCUSSION}

It is rare to encounter human sera that agglutinate stored red cells and leave fresh cells unaffected, but the phenomenon reported here is by no means unique; six other examples have been previously described (1-4). Clinical diagnoses of the affected patients have included idiopathic acquired hemolytic anemia, Hodgkin's disease, and carcinoma of the breast and ovaries. Although a definitive diagnosis was not made on the present patient, there were many of the characteristics of Waldenström's macroglobulinemia (36). Weak agglutination of stored cells was also demonstrated by sera from two other patients with macroglobulinemia and one patient with $\beta_{2 \Delta}$ myeloma.

Previously published descriptions of stored-cell agglutinins have not included detailed characterization of the responsible serum factor(s) by means of more recently developed laboratory techniques. The serum described by Brendemoen (1) agglutinated stored cells more strongly in the cold than at room temperature or $37^{\circ} \mathrm{C}$. Since the commonly encountered cold agglutinins are macroglobulins $(7,37)$, it is likely that the responsible factor in Brendemoen's patient was a high-molecular-weight serum globulin. The same inference may possibly be justified for Jenkins' and Marsh's patient (4) whose serum agglutinated stored cells at both low and high temperatures. In two other instances $(2,3)$, however, sera were reported to be optimally active at $37^{\circ} \mathrm{C}$, suggesting that the responsible factors were more likely to have been $7 \mathrm{~S}_{20, w}$ serum globulins (37).

In the present instance, the serum's ability to cause agglutination of stored red cells has been shown to reside in the macroglobulin component; the evidence is its concentration $a$ ) in the highmolarity effluent from the DEAE-cellulose column (Figure 2) $(14), b$ ) in the first peak from the Sephadex G-200 column (Figure 2) (15), and c) in the bottom fraction after sucrose gradient density ultracentrifugation (Figure 1) ( 7 ). That it is the $18.8 \mathrm{~S}_{\mathbf{2 0 , w}}$ fraction rather than the 28.8

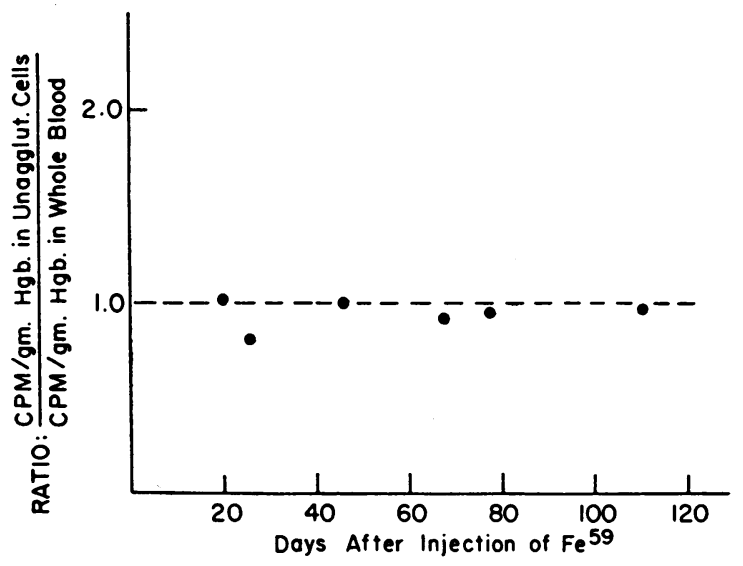

Fig. 6. FE Fi $^{30}$ ACTIVITY PER GRAM OF HEMOGLOBIN IN STORED BLOOD FROM WHICH AGGLUTINABLE CELLS HAVE BEEN REMOVED COMPARED WITH ACTIVITY IN WHOLE BLOOD. Results indicate that development of agglutinability during storage is unrelated to in vivo chronological cell age. 
$\mathrm{S}_{\mathbf{2 0 , w}}$ fraction that is responsible for the agglutinating activity is indicated by the retention of agglutinating activity despite the loss of the $28.8 \mathrm{~S}_{20 \text {,w }}$ peak in the ultracentrifugation pattern of postdialysis serum after treatment with $\mathrm{Na}$ arsenite (Figure 3). Integrity of the whole $18.8 \mathrm{~S}_{\mathbf{2 0 , w}}$ molecule appears to be necessary for maintenance of the agglutinating property, since agglutination no longer occurs when the molecule is broken down into smaller subunits after treatment with disulfide-splitting agents. Similar loss of activity after S-S cleavage has been reported for a variety of macromolecular agglutinins by other workers $(38,39)$.

The inhibition of agglutinating activity without breakdown of the $18.8 \mathrm{~S}_{20, w}$ globulins after treatment with PMB, GSSG, Na arsenite, and NEM cannot be attributed to the SH-binding properties of these compounds. It is not definitely known that there are any free $\mathrm{SH}$ groups on intact or pathological gamma macroglobulins. None of the reagents is entirely specific for thiol groups, and SH-binding would not be reversible after simple dialysis against buffered saline. No conclusions can be drawn from the limited evidence in hand, and an interpretation of the important inhibition phenomenon must await results of more definitive studies.

The relation of the present macroglobulin to normal macroglobulin remains obscure. Macroglobulin concentrated from a pool of normal plasma caused no agglutination of stored cells that gave a $4+$ reaction with the patient's serum. The stored-cell agglutinin reaction can be distinguished from anti-T agglutination (12), since it is not observed with normal sera and since the alteration of the red-cell surface takes place during storage under sterile conditions.

The results of the present investigation indicate that the development of agglutinability is closely related to the alterations in erythrocyte glucose metabolism taking place during in vitro storage. The importance of metabolic factors was first suggested by the relationship of agglutinability to the temperature of storage and to the characteristics of the anticoagulant solution (Tables I and II) ; agglutinability increased with conditions favoring depletion of glucose and consequent depletion of high-energy phosphate compounds. These observations were extended by studies em- ploying purine nucleosides, notably adenosine, which have been shown to improve the viability of stored red cells (29-31) either $a$ ) by conversion at the red-cell membrane to ribose 5-phosphate, which can be further metabolized with resultant regeneration of $\mathrm{ADP}$ and $\mathrm{ATP}(40-47)$, or $b$ ) by providing the purine moiety to serve as substrate for ATP synthesis $(30,48,49)$. Adenosine was able to restore many agglutinable cells to the unagglutinable state (Table III) when added after storage, and it delayed the development of agglutinability if present during storage. It was particularly remarkable that when adenosine was added to stored cells already agglutinated by $\mathrm{MG}$ serum, many of the cells detached themselves from the formed agglutinates, presumably reflecting a restorative effect on their metabolism.

Under normal conditions, the red cell derives its energy entirely from the metabolism of glucose, approximately $90 \%$ via the glycolytic (Embden-Meyerhof) pathway and $10 \%$ via the oxidative hexose monophosphate shunt $(50,51)$. If the beneficial effects of adenosine on agglutinability of stored cells were related to restoration of cellular metabolism, increased agglutinability should result from treatment with compounds interfering with cellular metabolism. MB provides a case in point, although its metabolic effects are numerous and complex. It is known to stimulate the hexose monophosphate shunt and to increase glucose utilization and $\mathrm{CO}_{2}$ formation; in the presence of $\mathrm{MB}$, erythrocyte oxygen uptake may increase as much as twentyfold (52-54). Even in the absence of glucose, increased uptake of oxygen is observed that presumably results from utilization of intracellular phosphate esters (51); the rate of breakdown of triose phosphate is increased, and lactate is oxidized to pyruvate (53, $55)$. Washed red cells contain almost no glucose and limited amounts of other substrates (56). In the presence of $\mathrm{MB}$, these substrates will be rapidly exhausted, which may explain the mechanism whereby fresh red cells are rendered agglutinable in its presence. The interpretation is consistent with the finding that substrate provided in the form of glucose or adenosine inhibited or reversed the agglutination-inducing effect of MB.

The effect of MB on G6PD-deficient cells differs from its effects on normal cells. Not only does the hexose monophosphate shunt fail, but 
pentose phosphate is not returned to the glycolytic pathway from the pentose shunt (57). Fructose 6-phosphate and triose phosphate become undetectable, and glucose accumulates (53). These differences may at least partly account for the more pronounced effect of $\mathrm{MB}$ in inducing agglutinability of G6PD-deficient cells and the lack of a protective or ameliorative effect of added glucose. It is difficult to understand why adenosine failed to counteract the effects of $\mathrm{MB}$, at least in part, since Carson (57) has shown that G6PDdeficient cells are capable of metabolizing inosine in the presence of $\mathrm{MB}$ and since a restorative effect of adenosine was observed after its addition to G6PD-deficient cells stored in the absence of $\mathrm{MB}$.

2-Desoxy-D-glucose has been shown to inhibit glycolysis and the growth of yeast $(58,59)$ and various animal tissues $(60-64)$. It is phosphorylated by hexokinase (65), but is not further metabolized, or else is metabolized only slowly; it also inhibits fructokinase, phosphohexoseisomerase, and G6PD in cultured human cells (66), and decreases levels of ATP in human red cells (67). In the present study, 2-desoxy-D-glucose rendered fresh cells agglutinable by $\mathrm{Mg}$ serum. At low concentrations of 2-desoxy-D-glucose (1.6 to 6.4 mmoles per $\mathrm{ml}$ cells), its deleterious effect was preventable or reversible by glucose or adenosine.

Iodacetate, arsenate, arsenite, and fluoride inhibit various enzymes and intermediate reactions in the glycolytic pathway of glucose metabolism $(40,57,59,67-71)$. Fresh red cells became agglutinable in the presence of concentrations of these reagents comparable to those employed by other workers to demonstrate inhibitory effects on glucose metabolism. Since agglutinability was not affected by addition of adenosine, it is likely that irreversible changes had taken place in the various enzymes affected by the inhibitory reagents.

Phlorizin inhibits the transport of glucose across cell membranes $(72,73)$ as well as inhibiting intracellular glucose metabolism at various steps (74). Although the effects of phlorizin on glucose transport have been confirmed for the human red cell $(72,73)$, its effects on erythrocyte glucose metabolism have not been adequately studied. In the present experiments, whether by its membrane effect or its effect on intracellular metabolism, phlorizin rendered fresh cells agglutinable by $M G$ serum.

$\mathrm{PMB}$ at low concentrations ( 1 to $3 \mu$ moles per $\mathrm{ml}$ cells) binds to $\mathrm{SH}$ groups on the red-cell membrane and slightly stimulates glycolysis (75); at higher concentrations (up to 7 mmoles per $\mathrm{ml}$ cells), it inhibits the pentose pathway (76). Its effect on red-cell nucleotides, however, is not marked. In the present studies, PMB did not affect agglutinability of fresh cells until it was used at a concentration of 0.4 mmole per $\mathrm{ml}$ cells, or higher. It is not possible to state whether its effect was mediated through $\mathrm{SH}$ binding on the red-cell surface, or inhibition of cellular glucose metabolism, or both. At a concentration of 2.5 $\mu$ moles per $\mathrm{ml}$ cells, NEM, another $\mathrm{SH}$ reagent, is known to bind to membrane $\mathrm{SH}$ groups and enter the red cell where it binds intracellular GSH ; red-cell glucose consumption and lactate production are impaired (75). At higher concentrations of NEM, inhibition of the pentose pathway occurs (76). In this study, NEM did not affect agglutinability of fresh cells until it was used at a concentration of 2 mmoles per $\mathrm{ml}$ cells, or higher. As in the case of PMB, judgment must be reserved on the relative importance of the various mechanisms of NEM's effect on agglutinability of fresh red cells.

If agglutinability of red cells is related to disturbance of their glucose metabolism, as our study strongly suggests, then integrity of the red-cell membrane is intimately linked with that of cellular metabolism. Interference with glucose metabolism at different levels leads to at least one common result, namely, depletion of ATP, and this is also observed when red cells are stored in vitro $(12,40,71,77,78)$. It is not certain whether ATP functions directly to maintain membrane integrity, but very close relationship is suggested by the response to adenosine, which both replenishes ATP and prevents or diminishes agglutinability of stored cells. Although spontaneous hemolysis has been reported to increase when intracellular GSH is depleted (79), diminished intracellular GSH per se was not accompanied by agglutinability. There is no direct evidence that GSH decreases on storage (80); fresh G6PDdeficient cells and GSH-deficient elliptic cells were not agglutinable (Table VIII), and binding 
of GSH by low concentrations of NEM (75) (2.5 $\mu$ moles per $\mathrm{ml}$ cells) did not result in agglutinability.

Agglutinability does not appear to be related to depletion of membrane lipids. Cells treated with alumina were not agglutinable, and the restorative effects of adenosine cannot be explained in terms of membrane lipids (81). The effect of proteolytic enzymes to enhance agglutinability (Table VII) and the inhibition of absorption of agglutinin after pretreatment of cell ghosts with PMB (Table VI) suggest that the fundamental alteration responsible for agglutinability involves the protein moiety of the cell membrane.

Results of preliminary studies with hematologically abnormal cells (Table VIII and IX) are of considerable interest. The presence of a small number of agglutinable cells in fresh blood from patients with sickle-cell anemia raises the possibility of an abnormality of the erythrocyte membrane in this disease either consequent upon or possibly unrelated to the abnormality of hemoglobin structure. The enhanced effects of storage upon cells from patients with thalassemia minor, iron-deficiency anemia, and Coombs-positive acquired hemolytic anemia suggest a pre-existing abnormality in the cell membranes, or impaired glucose metabolism, or both, in these pathologic erythrocytes. Evidence for metabolic abnormalities in red cells from patients with acquired hemolytic anemia has been reported by Altman, Tabechian, and Young (82) and by Storti, Vaccari, and Baldini (83).

The most provocative question raised by the present studies concerns the relationship of cell viability to agglutinability. Normal-donor blood stored in ACD solution under conventioral blood bank conditions contains approximately 25 to $30 \%$ of nonviable cells after 21 days of storage. The same blood contains approximately 25 to $30 \%$ of cells that will agglutinate on exposure to MG serum. If the agglutinable cells were the nonviable cells, then stored blood from which the agglutinable cells had been removed should exhibit normal in vivo survival. The results illustrated in Figure 5 throw considerable light on the problem, but do not provide a conclusive answer. Thirty per cent of the cells in the control bloods were so severely damaged that they were removed from the recipient's circulation within 1 hour af- ter transfusion. Blood from which the agglutinable cells had been separated showed $98 \%$ of the cells to be surviving 1 hour after transfusion. Thus, there appears to be a close correlation between nonviability and agglutinability as judged by the 1-hour survival data. An additional loss of $30 \%$ of the transfused cells, however, occurred between 1 and 48 hours after transfusion; the magnitude and pattern of cell destruction were indistinguishable between the control cells and the unagglutinable cells obtained after exposure to MG serum. By conventional criteria, cells destroyed within 24 to 48 hours of transfusion are considered "nonviable." The possibility remained that the cells disappearing from the recipient's circulation between hours 1 and 48 were damaged, but not irreversibly so, and might recover normal viability if appropriately treated. Strong support for this hypothesis comes from the virtually normal survival of unagglutinable stored cells treated with adenosine for 1 hour before transfusion.

The relationship of agglutinability to nonviability is not so straightforward as it may seem from the foregoing discussion. Technical difficulties made it impossible to measure accurately the number of cells removed as agglutinates before transfusion; in 30-day stored blood not treated with adenosine, the number of agglutinable cells was estimated to be $30 \%$. The size and number of agglutinates, however, appeared to be distinctly less in stored blood after treatment with adenosine; the number of agglutinable cells was perhaps only $15 \%$ of the total. Yet survival of adenosinetreated blood was virtually normal. These results suggest that not all the agglutinable cells in stored blood are irretrievably nonviable. Furthermore, blood stored in ACD at $4^{\circ} \mathrm{C}$ for 8 weeks reveals over $90 \%$ agglutinable cells, yet it is known that $60 \%$ of the cells are capable of normal in vivo survival after treatment with adenosine (12). A further complication is illustrated by the study of in vivo survival of bromelin-treated cells. Here, although the transfused cells gave a $4+$ agglutination reaction (i.e., $>$ $90 \%$ of cells agglutinable), their in vivo destruction was not so rapid as might have been expected: $11 \%$ destruction by 1 hour, $29 \%$ by 3 hours, and $78 \%$ by 20.5 hours. This contrasts with the rapid destruction (within 1 hour) of the presumed agglutinable cells in the control stored bloods. We 
conclude, then, that although a direct parallel cannot be drawn between agglutinability and nonviability, the data shown in Figure 5 support an important and close relationship between the two phenomena.

A less direct parallel between agglutinability and nonviability is provided by the data in Figure 6 indicating that development of agglutinability is not related to in vivo chronological cell age. Similarly, it is known from in vivo survival studies that nonviable cells in stored blood are a random sample of the cell population and do not represent the chronologically "old" donor cells (12). The latter finding has become more understandable in the light of recent chemical studies comparing in vivo and in vitro aging: the former is characterized primarily by a fall in enzyme levels (84), and the latter, by a decline in highenergy phosphate compounds $(71,78)$, while enzyme levels remain uncharged (85).

If the stored-cell agglutination phenomenon is to be considered an example of autoimmune disease, it must be established that the peculiar properties of the patient's serum were somehow responsible for her disease. She exhibited anemia and a reduced red-cell life-span when she was admitted to the hospital, but there is no positive evidence that the hemolytic anemia resulted from her serum's capacity to agglutinate stored cells. Jenkins and Marsh (4) have suggested that the red cell aged in vivo might act as an antigen. As discussed above, however, the aging of red cells in vivo and in vitro are different processes, and the results in Figure 6 indicate that red cells "aged" in vitro become agglutinable in a random fashion, unrelated to their chronological age. Furthermore, after splenectomy the patient's anemia did not recur, despite persistence of high concentrations of the pathologic macroglobulin in her serum. It is tempting to speculate that the metabolism-dependent alteration in the red-cell membrane had a counterpart in in vivo membrane changes in other tissue cells, with the exposure or creation of new antigenic sites responsible for stimulating antibody formation. There is no evidence from the present study to support this view, nor is it by any means certain that the macroglobulin should be classified as an "antibody." Red-cell agglutination may occur in the absence of antibody (86), and caution should be exercised before interpreting stored-cell agglutination as a true antigen-antibody reaction.

In the light of the above discussion and until there is more evidence from similar patients, interpretation of the physiologic significance of the stored-cell agglutinins must remain open and judgment reserved on whether they are autoimmune phenomena. As a means for the study of erythrocyte physiology, they have great promise, since important insights are sure to follow from increasing knowledge of the precise changes they detect in the membranes of normal and pathologic human red cells.

\section{SUMMARY}

Serum from a patient with macroglobulinemia was observed to cause strong agglutination of stored human red cells but to leave fresh cells unaffected. By means of column chromatography and sucrose gradient density ultracentrifugation, the agglutinating activity was shown to reside in the macroglobulin fraction of the serum. Agglutinating activity was irreversibly abolished when the macroglobulin was broken down by disulfidesplitting reagents. Agglutinating activity was abolished by exposure of the serum to $p$-hydroxymercuribenzoate, $\mathrm{Na}$ arsenite, and glutathione, but was restored after dialysis. The agglutinating activity of the serum was irreversibly abolished by exposure to $N$-ethylmaleimide.

Studies carried out to characterize conditions under which stored human red cells become agglutinable included the effects of temperature of storage, anticoagulant solutions, agents favorable to red-cell metabolism (glucose, adenosine, inosine, and adenine), agents deleterious to red-cell metabolism (methylene blue, 2-desoxy-D-glucose, phlorizin, arsenite, arsenate, iodoacetate, fluoride), $p$-hydroxymercuribenzoate and $N$-ethylmaleimide, proteolytic enzymes (trypsin, papain, ficin, bromelin, and neuraminidase), and depletion of membrane lipid (alumina).

The agglutinability of red cells from 30 patients with hematologic abnormalities is reported. Notable were the findings of a small proportion of agglutinable cells in freshly drawn blood from all of five patients with sickle-cell anemia, and more rapid than normal development of agglutinability by cells from patients with thal- 
assemia minor, iron-deficiency anemia, and Coombspositive acquired hemolytic anemia. Nine units of stored blood (mean duration of storage, 30.5 days) was employed for fifteen in vivo red-cell survival studies. A close relationship was demonstrated between agglutinability and nonviability of the cells. Studies of agglutinability in stored samples obtained from a volunteer after injection of $\mathrm{Fe}^{59}$ demonstrated that development of agglutinability during storage was unrelated to chronological red-cell age. The dependence of agglutinability on disordered red-cell metabolism was discussed and the implications of the stored-cell agglutination phenomenon were briefly reviewed.

\section{ACKNOWLEDGMENTS}

We are especially grateful to Dr. David Miller for making available the clinical information and hospital laboratory data and for obtaining the supplies of patient's plasma that made these investigations possible; to Drs. Anthony Fletcher and Norma Alkjaersig and Miss Carmelita Lowry for aid with the ultracentrifugation studies; to Dr. Henry Kunkel of the Rockefeller Institute, New York, for helpful discussion and for aid with the sucrose gradient density ultracentrifugation study; and to Dr. S. E. Ritzmann, University of Texas Medical Branch, Galveston, Tex., for performing the immunoelectrophoresis.

\section{REFERENCES}

1. Brendemoen, O. J. A cold agglutinin specifically active against stored red cells. Acta path. microbiol. scand. 1952, 31, 574.

2. Hougie, C., J. Dandridge, and O. B. Bobbitt. A new autoagglutinin against stored erythrocytes. Proc. 7th Congr. int. Soc. Blood Transf., Rome, 1958, 252.

3. Stratton, F., P. H. Renton, and V. I. Rawlinson. Serological differences between old and young cells. Lancet 1960, 1, 1388.

4. Jenkins, W. J., and W. L. Marsh. Autoimmune hæmolytic anæmia. Three cases with antibodies specifically active against stored red cells. Lancet 1961, 2, 16.

5. Franklin, E. C., and D. R. Stanworth. Antigenic relationships between immune globulins and certain related paraproteins in man. J. exp. Med. 1961, 114, 521.

6. Wieme, R. J. An improved technique of agargel electrophoresis on microscope slides. Clin. chim. Acta 1959, 4, 317.

7. Kunkel, H. G. Macroglobulins and high molecular weight antibodies in The Plasma Proteins, F. W. Putnam, Ed. New York, Academic Press, 1960, p. 294.
8. Wiener, A. S., L. J. Unger, L. Cohen, and J. Feldman. Type-specific cold auto-antibodies as a cause of acquired hemolytic anemia and hemolytic transfusion reactions: biologic test with bovine red cells. Ann. intern. Med. 1956, 44, 221.

9. Chaplin, H., Jr., and M. Cassell. Studies on antieiuate sera. I. The production of antiglobulin (Coombs) sera in rabbits by the use of antibodies eluted from sensitized red blood cells. Vox Sang. (Basel) 1960, 5, 32.

10. Lovelock, J. E. The physical instability of human red blood cells. Biochem. J. 1955, 60, 692.

11. Anderson, R., M. Cassell, G. L. Mullinax, and H. Chaplin, Jr. Effect of normal cells on viscosity of sickle-cell blood. Arch. intern. Med. 1963, 111, 286.

12. Mollison, P. L. Blood Transfusion in Clinical Medicine, 3rd ed. Oxford, Blackwell, 1961.

13. Ebaugh, F. G., Jr., C. P. Emerson, and J. F. Ross. The use of radioactive chromium ${ }^{51}$ as an erythrocyte tagging agent for the determination of red cell survival in vivo. J. clin. Invest. 1953, 32, 1260.

14. Fahey, J. L., P. F. McCoy, and A. P. Horbett. Chromatographic characterization of the serum protein changes in pathologic sera (abstract). J. clin. Invest. 1958, 37, 893.

15. Gelotte, B., P. Flodin, and J. Killander. Fractionation of human plasma proteins by gel filtration and some electrophoresis or ion-exchange chromatography. Arch. Biochem. 1962, 98, suppl. 1, 319.

16. Ritzmann, S. E., and W. C. Levin. Cryopathies: a review. Arch. intern. Med. 1961, 107, 754.

17. Du Vigneaud, V., A. Fitch, E. Pekarek, and W. W. Lockwood. The inactivation of crystalline insulin by cysteine and glutathione. J. biol. Chem. 1931-2, 94, 233.

18. Wieland, T. Chemistry and properties of glutathione in Glutathione, A Symposium. New York, Academic Press, 1954, p. 45.

19. Vennesland, B., and E. E. Conn. The enzymatic oxidation and reduction of glutathione in Glutathione, A Symposium. New York, Academic Press, 1954, p. 105.

20. Racker, E. Glutathione as a coenzyme in intermediary metabolism in Glutathione, A Symposium. New York, Academic Press, 1954, p. 165.

21. Hopkins, F. G., and E. J. Morgan. The influence of thiol-groups in the activity of dehydrogenases. Biochem. J. 1938, 32, 611.

22. Cecil, R., and J. R. McPhee. The sulfur chemistry of proteins. Advanc. Protein Chem. 1959, 14, 255.

23. Barron, E. S. G. Thiol groups of biological importance. Advanc. Enzymol. 1951, 11, 201.

24. Barron, E. S. G., Z. B. Miller, G. R. Bartlett, J. Meyer, and T. P. Singer. Reactivation by dithiols of enzymes inhibited by lewisite. Biochem. J. 1947, 41, 69. 
25. Peters, R. A., H. M. Sinclair, and R. H. S. Thompson. An analysis of the inhibition of pyruvate oxidation by arsenicals in relation to the enzyme theory of vesication. Biochem. J. 1946, 40, 516.

26. Stocken, L. A., and R. H. S. Thompson. British anti-lewisite. I. Arsenic derivatives of thiol proteins. Biochem. J. 1946, 40, 529.

27. Smyth, D. G., A. Nagamatsu, and J. S. Fruton. Some reactions of $N$-ethylmaleimide. J. Amer. chem. Soc. 1960, 82, 4600.

28. Loutit, J. F., and P. L. Mollison. Advantages of a disodium-citrate-glucose mixture as a blood preservative. Brit. Med. J. 1943, 2, 744.

29. Gabrio, B. W., D. M. Donohue, F. M. Huennekens, and C. A. Finch. Erythrocyte preservation. VII. Acid-citrate-dextrose-inosine (ACDI) as a preservative for blood during storage at $4^{\circ} \mathrm{C}$. J. clin. Invest. 1956, 35, 657.

30. Mollison, P. L., and M. A. Robinson. Observations on the effects of purine nucleosides on red-cell preservation. Brit. J. Haemat. 1959, 5, 331.

31. Prankerd, T. A. J. Revival of stored blood with guanosine and its successful transfusion. Lancet 1956, 1, 469.

32. Simon, E. R., R. G. Chapman, and C. A. Finch. Adenine in red cell preservation. J. clin. Invest. 1962, 41, 351.

33. Lovelock, J. E. Hemolysis by thermal shock. Brit. J. Haemat. 1955, 1, 117.

34. Dacie, J. V. Hemolytic anemias, Part I, 2nd ed. London, Churchill, 1960, p. 156.

35. De Gruchy, G. C., P. B. Loder, and I. V. Hennessy. Hemolysis and glycolytic metabolism in hereditary elliptocytosis. Brit. J. Haemat. 1962, 8, 168.

36. Waldenström, J. Incipient myelomatosis or "essential" hyperglobulinemia with fibrinogenopenia-a new syndrome? Acta med. scand. 1944, 117, 216.

37. Dacie, J. V. Hemolytic Anemias, Part II, 2nd ed. London, Churchill, 1962, p. 499.

38. Deutsch, H. F., and P. C. Y. Chan. Human serum hemagglutinins. Fed. Proc. 1958, 17, 210.

39. Fudenberg, H. H., H. G. Kunkel, and E. C. Franklin. High molecular weight antibodies. Proc. 7th Congr. int. Soc. Blood Transf., Rome, 1958, 522.

40. Prankerd, T. A. J., and K. I. Altman. A study of the metabolism of phosphorous in mammalian red cells. Biochem. J. 1955, 58, 622.

41. Gabrio, B. W., M. Hennessey, J. Thomasson, and C. A. Finch. Erythrocyte preservation. IV. In itro reversibility of the storage lesion. J. biol. Chem. 1955, 215, 357.

42. Lowy, B. A., E. R. Jaffé, G. A. Vanderhoff, L. Crook, and I. M. London. The metabolism of purine nucleosides by the human erythrocyte in vitro. J. biol. Chem. 1958, 230, 409.
43. Prankerd, T. A. J. Chemical changes in stored blood, with observations on the effects of adenosine. Biochem. J. 1956, 64, 209.

44. Huennekins, F. M., E. Nurk, and B. W. Gabrio. Erythrocyte metabolism. I. Purine nucleoside phosphorylase. J. biol. Chem. 1956, 221, 971.

45. Rubinstein, D., S. Kasher, and O. F. Denstedt. Studies on the preservation of blood. IV. The influence of adenosine on the glycolytic activity of the erythrocyte during storage at $4^{\circ} \mathrm{C}$. Canad. J. Biochem. 1956, 34, 61.

46. Lowy, B. A., B. Ramot, and I. M. London. Adenosine triphosphate metabolism in the rabbit erythrocyte in vivo and in vitro. Ann. N. Y. Acad. Sci. 1958, 75, 148.

47. Nakao, M., T. Nakao, M. Tatibana, and H. Yoshikawa. Phosphorous metabolism in human erythrocytes. III. Regeneration of adenosine triphosphate in long-stored erythrocyte by incubation with inosine and adenine. J. Biochem. (Tokyo) $1960,47,661$.

48. Overgaard-Hansen, S., K. Jørgensen, and E. Prætorius. Rephosphorylation produced by inosine and adenosine of adenosine monophosphate and adenosine diphosphate in human erythrocytes. Nature (Lond.) 1956, 179, 152.

49. Hughes-Jones, N. C., P. L. Mollison, and M. A. Robinson. Factors affecting the viability of erythrocytes stored in the frozen state. Proc. roy. Soc. B 1957, 147, 476.

50. Murphy, J. R. Erythrocyte metabolism. II. Glucose metabolism and pathways. J. Lab. clin. Med. 1960, 55, 286.

51. Prankerd, T. A. J. The Red Cell. Oxford, Blackwell, 1961, p. 61.

52. Harrop, G. A., Jr., and E. S. G. Barron. Studies on blood cell metabolism. I. The effect of methylene blue and other dyes upon the oxygen consumption of mammalian and avian erythrocytes. J. exp. Med. 1928, 48, 207.

53. Fornaini, G., G. Leoncini, L. Luzzatto, and G. Segni. Glucose metabolism in human erythrocytes from normal and fava bean-sensitive subjects. J. clin. Invest. 1962, 41, 1446.

54. Szeinberg, A., and P. A. Marks. Substances stimulating glucose catabolism by the oxidative reactions of the pentose phosphate pathway in human erythrocytes. J. clin. Invest. 1961, 40, 914.

55. Wendel, W. B. Oxidation of lactic acid by dog erythrocytes. Proc. Soc. exp. Biol. (N. Y.) 1929, 26, 865 .

56. Bartlett, G. R. Methods for the isolation of glycolytic intermediates by column chromatography with ion exchange resins. J. biol. Chem. 1959, 234, 459 .

57. Carson, P. E. Glucose-6-phosphate dehydrogenase deficiency in hemolytic anemia. Fed. Proc. 1960, 19, 995. 
58. Cramer, F. B., and G. E. Woodward. 2-Deoxy-Dglucose as an antagonist of glucose in yeast fermentation. Franklin Inst. J. 1952, 253, 354.

59. Woodward, G. E. 2-Deoxy-D-glucose as an inhibitor in the aerobic glucose metabolism of yeast. Franklin Inst. J. 1952, 254, 553.

60. Woodward, G. E., and M. T. Hudson. The effect of 2-deoxy-D-glucose on glycolysis and respiration of tumor and normal tissues. Cancer Res. 1954, 14, 599.

61. Ely, J. O., F. A. Tull, and J. A. Hard. The influence of 2-deoxy-D-glucose on the growth of embryonic chicken-heart fibroblasts in tissue cultures. Franklin Inst. J. 1952, 253, 361.

62. Nirenberg, M. W., and J. F. Hogg. Inhibition of anaerobic glycolysis in Ehrlich ascites tumor cells by 2-deoxy-D-glucose. Cancer Res. 1958, 18, 518.

63. Tower, D. B. The effects of 2-deoxy-D-glucose on metabolism of slices of cerebral cortex incubated in vitro. J. Neurochem. 1958, 3, 185.

64. Ball, H. A., A. N. Wick, and C. Sanders. Influence of glucose antimetabolites on the Walker tumor. Cancer Res. 1957, 17, 235.

65. Sols, A., and R. K. Crane. Substrate specificity of brain hexokinase. J. biol. Chem. 1954, 210, 581.

66. Barban, S., and H. O. Schulze. The effects of 2-deoxyglucose on the growth and metabolism of cultured human cells. J. biol. Chem. 1961, 236, 1887.

67. Bishop, C. Factors in the in vitro maintenance of the nucleotide pattern of whole human blood. Transfusion 1961, 1, 355.

68. Rapkine, L. Sulfhydryl groups and enzymic oxidoreduction. Biochem. J. 1938, 32, 1729.

69. Gourley, D. R. H. The role of adenosine triphosphate in the transport of phosphate in the human erythrocyte. Arch. Biochem. 1952, 40, 1.

70. Guest, G. M., and S. Rapaport. Organic acid-soluble phosphorus compounds of the blood. Physiol. Rev. 1941, 21, 410.

71. Bartlett, G. R., and H. N. Barnet. Changes in the phosphate compounds of the human red blood cell during blood bank storage. J. clin. Invest. 1960, $39,56$.
72. LeFevre, P. G. The evidence for active transport of monosaccharides across the red cell membrane. Symp. Soc. exp. Biol. 1954, 8, 118.

73. Wilbrandt, W. Secretion and transport of nonelectrolytes. Symp. Soc. exp. Biol. 1954, 8, 136.

74. Lotspeich, W. D. Phlorizin and cellular transport of glucose. Harvey Lect. 1960-1, 56, 63.

75. Jacob, H. S., and J. H. Jandl. Effects of sulfhydryl inhibition on red blood cells. I. Mechanism of hemolysis. J. clin. Invest. 1962, 41, 779.

76. Sheets, R. F., and H. E. Hamilton. A reversible effect on the metabolism of human erythrocytes by $p$-chloromercuribenzoic acid and $N$-ethylmaleimide. J. Lab. clin. Med. 1958, 52, 138.

77. Maizels, M. Factors in the active transport of cations. J. Physiol. (Lond.) 1951, 112, 59.

78. Bishop, C. Changes in the nucleotides of stored or incubated human blood. Transfusion 1961, 1, 349.

79. Fegler, G. Relationship between reduced glutathione content and spontaneous hæmolysis in shed blood. Nature (Lond.) 1952, 170, 624.

80. Szeinberg, A., C. Sheba, and A. Adams. Storage stability of blood with unstable glutathione. Israel med. J. 1958, 17, 265.

81. Buchanan, A. A. Lipid synthesis by human leukocytes in vitro. Biochem. J. 1960, 75, 315.

82. Altman, K. I., H. Tabechian, and L. E. Young. Some aspects of the metabolism of red blood cells from patients with hemolytic anemias. Ann. N. Y. Acad. Sci. 1959, 75, 142.

83. Storti, E., F. Vaccari, and E. Baldini. Changes in red cells metabolism in presence of incomplete antibodies. Experientia (Basel) 1956, 12, 108.

84. Marks, P. A., A. B. Johnson, and E. Hirschberg. Effect of age on the enzyme activity in erythrocytes. Proc. nat. Acad. Sci. (Wash.) 1958, 44, 529.

85. Marks, P. A., A. B. Johnson, R. deBellis, and J. Banks. Stability of metabolism of erythrocytes stored in vitro. Fed. Proc. 1958, 17, 269.

86. Jandl, J. H., and R. L. Simmons. The agglutination and sensitization of red cells by metallic cations: interactions between multivalent metals and the red-cell membrane. Brit. J. Haemat. 1957, 3, 19. 